\title{
Prevalence and intensity study of dental caries in children with bronchial asthma
}

\author{
0. V. Voznyi ${ }^{F}$, T. Ye. Shumna*E, Ye. S. Lepetchenko ${ }^{A, B, C, D}$
}

Zaporizhzhia State Medical University, Ukraine

A - research concept and design; B - collection and/or assembly of data; C - data analysis and interpretation; D - writing the article;

$\mathrm{E}$ - critical revision of the article; $\mathrm{F}$ - final approval of the article

prevalence,

intensity, caries,

bronchial asthma,

children.

\section{Zaporozhye}

medical journal

2020; 22 (3), 384-388

*E-mail:

tshumnaya72@

gmail.com
Key words:

Aim. To study the prevalence and intensity rates of dental caries in children with bronchial asthma.

Materials and methods. The examination of patients was carried out in the Allergological Department of the Communal Non-Profit Enterprise "City Children Hospital No. 5" in Zaporizhzhia. The study of the carious process prevalence included 158 children with bronchial asthma (50 girls, 108 boys), aged between 3 and 17 years. The study on the caries intensity included 148 children with bronchial asthma (47 girls, 101 boys), aged between 3 and 17 years, who had more than 1 caries cavity. These children were divided into three groups according to the indices of carious process intensity: DMF (permanent dentition, 79 children (20 girls, 59 boys) aged between 10 and 17 years), DMF + df (mixed dentition, 59 children (21 girls, 38 boys) aged between 5 and 14 years), df (primary dentition, 10 children ( 6 girls, 4 boys) aged between 3 and 6 years), where $D$ means decayed permanent teeth, $M$ missing permanent teeth, $\mathrm{F}$ - filled permanent teeth; $\mathrm{d}$ means decayed primary teeth, $\mathrm{f}-$ filled primary teeth. Each group was further divided into subgroups according to sex.

The control group included 20 non-asthmatic children ( 7 girls, 13 boys) aged between 5 and 10 years with carious lesions in teeth. The results were processed using the Statistica ${ }^{\circledR}$ for Windows 13.0 (StatSoft Inc., № JPZ804I382130ARCN10-J). The data on the carious process intensity were checked for normal distribution according to the Shapiro-Wilk test. Since the distribution was different from normal $(P<0.05)$, the data were presented as the median and lower and upper quartiles Me (Q25; Q75), and the differences were considered statistically significant at a P level of $<0.05$.

Results. The prevalence of caries in children with bronchial asthma was $95.5 \%$ indicating mass disease. In the group of children with a permanent dentition, the carious process of a high intensity was revealed with the DMF index equal to $6(4 ; 8) \min 1$, max 16 , while $75 \%$ of the children had a subcompensated and $25 \%$ had a compensated dental caries. In the studied group, the carious process intensity was significantly higher in boys: $6.0(4.5 ; 8.0)$ versus $5(4 ; 8)$, which testified to sex differences in the pathological process of the oral cavity. In the group of children with mixed dentition, the DMF + df index was equal to $7(4 ; 10)$ min 1 , max 14 , and indicated the carious process of a very high intensity and in this case, $25 \%$ of children had a compensated form of the carious process, $25 \%$ of children - subcompensated and $50 \%$ - decompensated form. When comparing the subgroups of girls and boys, age- and sex-related differences in the DMF + df index were not observed. The df index for the examined patients with a temporary dentition was equal to $4(2 ; 4) \min 1$, $\max 12$. When comparing the intensity of the carious process in the groups according to the Kruskal-Wallis test, a statistically significant difference was observed $(H=9.08, P=0.0107)$. In the period of a mixed dentition, the intensity of the carious process was higher in children with bronchial asthma than in somatically healthy children and amounted to $7(4 ; 10) \min 1, \max 14)$ versus $6.0(3.5 ; 8.0) \min 1, \max 10(P<0.05)$.

Conclusions. The study conducted for the state of dental hard tissues has proven the high prevalence and intensity of the carious process in children with bronchial asthma. In addition, the data obtained have enabled us to determine the presence of sex-specific characteristics and differences in the reported indicators in adolescents. This motivates us to study the dental health issues in children with bronchial asthma in the anamnesis and to develop specific programs for the prevention of dental caries.

Ключові слова: поширеність, інтенсивність, карієс, бронхіальна астма, Аіти.

\section{Запорізький} медичний журнал. 2020. T. 22, № 3(120). C. 384-388

\section{Аослідження поширеності та інтенсивності карієсу в дітей із бронхіальною астмою}

\section{О. В. Возний, Т. Є. Шумна, Є. С. Аепетченко}

Мета роботи - вивчити показники поширеності та інтенсивності карієсу в дітей із бронхіальною астмою.

Матеріали та методи. Пацієнтів обстежили на базі алергологічного відділення КНП «Міська дитяча лікарня № 5» м. Запоріжжя. У дослідження поширеності каріозного процесу залучили 158 дітей із бронхіальною астмою (50 дівчат, 108 хлопців) віком від 3 до 17 років. У дослідження інтенсивності карієсу залучили 148 дітей із бронхіальною астмою (47 дівчат, 101 хлопець), які мали понад 1 каріозну порожнину, вік пацієнтів - від 3 до 17 років. Дітей поділили на 3 групи за індексами інтенсивності каріозного процесу: КПВ (постійний прикус, 79 дітей (20 дівчат, 59 хлопців) віком від 10 до 17 років), КПВ + кп (змінний прикус, 59 дітей (21 дівчина, 38 хлопців) віком від 5 до 14 років), кп (тимчасовий прикус, 10 дітей (6 дівчат, 4 хлопчики) віком від 3 до 6 років), де К - каріозні постійні, П- пломбовані постійні, В - видалені постійні зуби; к - каріозні тимчасові, п - пломбовані тимчасові зуби). Кожну з груп додатково поділили на підгрупи за статтю пацієнтів. Контрольна група включала 20 дітей (7 дівчат, 13 хлопців) віком 5-10 років, здорових щодо бронхіальної астми і які мають каріозні ураження зубів. Результати опрацювали, використовуючи пакет ліцензійної програми Statistica ${ }^{\circledR}$ for Windows 13.0 (StatSoft Inc., № JPZ804I382130ARCN10-J). Результати дослідження інтенсивності каріозного процесу перевірили на нормальність розподілу даних за критерієм Шапіро-Уїлка. Оскільки розподіл відрізнявся від нормального $(p<0,05)$, показники наведені як медіана та нижній і верхній квартилі $\mathrm{Me}\left(Q_{25} ; Q_{75}\right)$, а різницю вважали вірогідною при рівні статистичної значущості $p<0,05$. 
Результати. Поширеність карієсу в дітей із бронхіальною астмою становила 95,5 \%, що свідчить про масову захворюваність. У групі дітей із постійним прикусом встановили високий рівень інтенсивності каріозного процесу з показником індексу КПУ 6 (4;8 ) min 1, max 16, при цьому 75 \% дітей мали субкомпенсовану форму, 25 \% дітей - компенсовану форму карієсу зубів. У групі дослідження інтенсивність каріозного процесу у хлопців була суттєво вищою - $6,0(4,5 ; 8,0)$ проти $5(4 ; 8)$, що свідчило про гендерні відмінності в перебігу патологічного процесу в порожнині рота. У групі дітей зі змінним прикусом індекс КПУ + кп становив $7(4 ; 10) \min 1$, max 14 і свідчив про дуже високу інтенсивність каріозного процесу; 25 \% дітей мали компенсовану форму, 25 \% дітей - субкомпенсовану форму, 50 \% дітей - некомпенсовану форму перебігу каріозного процесу. Порівнюючи підгрупи дівчат і хлопців, не виявили вікові та гендерні особливості щодо індексу КПУ + кп. Індекс кп в обстежених із групи з тимчасовим прикусом становив $4(2 ; 4) \min 1, \max 12$. Порівнюючи інтенсивність каріозного процесу у групах за критерієм Краскела-Уолліса, зареєстрували статистично значущу різницю ( $\mathrm{H}=9,08, p=0,0107)$. У періоді змінного прикусу в дітей із бронхіальною астмою інтенсивність каріозного процесу вища, ніж у соматично здорових дітей, становлячи $7(4 ; 10) \min 1, \max 14$ проти $6,0(3,5 ; 8,0) \min 1, \max 10(p<0,05)$.

Висновок. Дослідження стану твердих тканин зубів показало високий рівень поширеності та інтенсивності каріозного процесу в дітей із бронхіальною астмою. Результати дали можливість визначити наявність гендерних особливостей i відмінностей заявлених показників у дітей пубертатного віку. Це спонукає до продовження вивчення питань стоматологічного здоров'я дітей, які мають в анамнезі бронхіальну астму, та створення специфічних програм профілактики карієсу.

\section{Исследование распространенности и интенсивности кариеса у детей с бронхиальной астмой}

\section{А. В. Возный, Т. Е. Шумная, Е. С. Аепетченко}

Цель работы - изучить показатели распространенности и интенсивности кариеса у детей с бронхиальной астмой.

Материалы и методы. Обследование пациентов провели на базе аллергологического отделения КНП «Городская детская больница № 5» г. Запорожья. В клиническое исследование распространенности кариозного процесса включили 158 детей с бронхиальной астмой (50 девочек, 108 мальчиков) в возрасте от 3 до 17 лет. В исследование интенсивности кариеса включили 148 детей с бронхиальной астмой (47 девочек, 101 мальчик), имеющих более 1 кариозной полости, возраст от 3 до 17 лет. Детей разделили на три группы согласно индексам интенсивности кариозного процесса: КПУ (постоянный прикус, 79 детей (20 девочек, 59 мальчиков) в возрасте от 10 до 17 лет), КПУ + кп (сменный прикус, 59 детей (21 девочка, 38 мальчиков) в возрасте от 5 до 14 лет), кп (временный прикус, 10 детей (6 девочек, 4 мальчика) в возрасте от 3 до 6 лет), где К - кариозные постоянные, П - пломбированные постоянные, У - удаленные постоянные зубы; к - кариозные временные, п-пломбированные временные зубы). Каждая из групп дополнительно разделена на подгруппы по признаку пола пациентов. Контрольная группа включала 20 детей (7 девочек, 13 мальчиков) в возрасте 5-10 лет, здоровых относительно бронхиальной астмы и имеющих кариозные поражения зубов. Результаты обработаны с использованием пакета лицензионной программы Statistica ${ }^{\circledR}$ for Windows 13.0 (StatSoft Inc., № JPZ804I382130ARCN10-J). Данные по интенсивности кариозного процесса проверены на нормальность распределения данных согласно критерию Шапиро-Уилка. Поскольку распределение отличалось от нормального $(\mathrm{p}<0,05)$, данные представлены в виде медианы и нижнего и верхнего квартилей $\mathrm{Me}\left(Q_{25} ; Q_{75}\right)$, а различия считали достоверными при уровне статистической значимости $p<0,05$.

Результаты. Распространенность кариеса у детей с бронхиальной астмой составила 95,5 \%, что свидетельствует о массовой заболеваемости. В группе детей с постоянным прикусом отмечен высокий уровень интенсивности кариозного процесса с показателем индекса КПУ $6(4 ; 8) \min 1$, max 16; у 75 \% детей - субкомпенсированная форма, 25 \% - компенсированная форма кариеса зубов. В исследованной группе интенсивность кариозного процесса у мальчиков была существенно выше: $6,0(4,5 ; 8,0)$ против $5(4 ; 8)$, что свидетельствовало о гендерных отличиях в течении патологического процесса в полости рта. В группе детей со сменным прикусом индекс КПУ + кп составил $7(4 ; 10) \min 1, \max 14$ и свидетельствовал об очень высокой интенсивности кариозного процесса; 25 \% детей имели компенсированную форму, 25 \% детей - субкомпенсированную форму, 50 \% детей - декомпенсированную форму течения кариозного процесса. При сравнении подгрупп девочек и мальчиков возрастные и гендерные особенности относительно индекса КПУ + кп не установлены. Индекс кп у обследованных из группы с временным прикусом составил $4(2 ; 4) \min 1, \max 12$. При сравнении интенсивности кариозного процесса в группах по критерию Краскела-Уоллиса наблюдали статистически значимую разницу (H=9,08, p = 0,0107). В периоде сменного прикуса, у детей с бронхиальной астмой интенсивность кариозного процесса выше, чем у соматических здоровых и составила $7(4 ; 10) \min 1, \max 14)$ против $6,0(3,5 ; 8,0) \min 1, \max 10(p<0,05)$.

Выводы. Исследование состояния твердых тканей зубов показало широкую распространенность и высокий уровень интенсивности кариозного процесса у детей, больных бронхиальной астмой. Полученные данные дали возможность определить наличие гендерных особенностей и различий заявленных показателей у детей пубертатного возраста. Это обусловливает актуальность дальнейшего изучения вопросов стоматологического здоровья детей, имеющих в анамнезе бронхиальную астму, и создания специфических программ профилактики кариеса.

For many years, dental caries has remained one of the most common dental diseases among children [1]. In countries with a high level of preventive measures, the prevalence and intensity of the carious process has a stable tendency to decrease, at the same time, these indicators have been rising steadily in Ukraine [2]. So, the prevalence of caries among children in Ukraine reaches 90-100\%, while the intensity of the carious process remains high (4.5-6.0) in case of a subcompensated or decompensated form of the pathological process [3].

A number of external factors adversely affect the dental health of children. Among them are family history, socio-economic, educational, socio-hygienic and medical-organizational problems $[4,5]$. However, the state of general and local
Ключевые слова: распространенность, интенсивность, кариес, бронхиальная астма, Аети.

Запорожский медицинский журнал. 2020. T. 22, № 3(120). C. $384-388$ 
immunity and the presence of concomitant somatic pathology have the greatest influence. Moreover, the prevalence of allergic diseases over the past 10 years has increased from $10-30 \%$ to $50-60 \%$ in certain regions of the world [6]. One of the most common allergic diseases among children is bronchial asthma (1-18\% in the structure of somatic pathology) [7]. According to L. F. Kaskova, children who have respiratory system diseases in the anamnesis, including bronchial asthma, have a higher level of prevalence and intensity of the carious process [8]. This is explained by reactive changes in the composition of saliva and low tooth resistance to caries due to the influence of drugs for the basic treatment of bronchial asthma (inhaled glucocorticosteroids) [9]. In addition, inhaled glucocorticosteroids change the salivation rate, reduce $\mathrm{pH}$ of a dental plaque, increase the viscosity of saliva, and decrease the amount of secretory $\lg A$ [10-12]. These changes in the midst of body immunologic dysfunction, disorders of protein and mineral metabolism, tissue hypoxia and bone composition changes due to bronchial asthma, have a common effect on the dental status of patients, make them more vulnerable to dental caries and contribute to the development of a cariogenic situation in the oral cavity [13]. Nevertheless, the issue of the carious process prevalence and intensity among children has not been studied enough. This makes it possible for this problem to occupy one of the leading places among the tasks of modern pediatric dentistry [14].

\section{Aim}

To study the prevalence and intensity indicators of dental caries in children with bronchial asthma.

\section{Materials and methods}

The examination of patients was carried out in the Allergological Department of the Communal Non-Profit Enterprise "City Children Hospital No. 5" in Zaporizhzhia. The study on the carious process prevalence included 158 children with bronchial asthma ( 50 girls, 108 boys), aged between 3 and 17 years. The study on the caries intensity included 148 children with bronchial asthma (47 girls, 101 boys), aged

Table 1. Caries indicators

\begin{tabular}{l|l}
\hline Caries level & DMF, DMF+df, df intensity indicators \\
\hline Very low & $0.0-1.1$ \\
\hline Low & $1.2-2.6$ \\
\hline Medium & $2.7-4.4$ \\
\hline High & $4.5-6.5$ \\
\hline Very high & 6,6 and above \\
\hline
\end{tabular}

DMF: permanent dentition; DMF + df: mixed dentition; df: primary dentition; D: decayed permanent teeth; M: missing permanent teeth; F: filled permanent teeth; d: decayed primary teeth; f: filled primary teeth.

Table 2. Caries degrees

\begin{tabular}{l|l}
\hline Caries degree & DMF, DMF + df, df indicators \\
\hline The 1st degree. Compensated & $\leq 5$ \\
The 2nd degree. Subcompensated & From 6 to 8 \\
\hline The 3rd degree. Decompensated & $>8$ \\
\hline
\end{tabular}

DMF: permanent dentition; DMF + df: mixed dentition; df: primary dentition; D: decayed permanent teeth; M: missing permanent teeth; F: filled permanent teeth; d: decayed primary teeth; f: filled primary teeth. between 3 and 17 years, who had more than 1 dental decay cavity. These children were divided into three groups according to the carious process intensity rate: DMF (permanent dentition, 79 children ( 20 girls, 59 boys) aged between 10 and 17 years), DMF + df (mixed dentition, 59 children (21 girls, 38 boys) aged between 5 and 14 years), df (permanent dentition, 10 children ( 6 girls, 4 boys) aged between 3 and 6 years), where $D$ means decayed permanent teeth, $\mathrm{M}$ - missing permanent teeth, $\mathrm{F}$ - filled permanent teeth; $d$ means decayed permanent teeth, $f$ - filled permanent teeth. Each of the groups was further divided into subgroups according to sex.

The results were processed using the Statistica ${ }^{\circledR}$ for Windows 13.0 (StatSoft Inc., № JPZ804I382130ARCN10-J). The data on the carious process intensity were checked for normal distribution using the Shapiro-Wilk test. Since the distribution was different from normal $(P<0.05)$, the data were presented as the median and lower and upper quartiles $\mathrm{Me}(\mathrm{Q} 25 ; \mathrm{Q} 75)$. Due to the fact that the greatest prevalence of the carious lesion was observed in the mixed dentition group (DMF + df index, children aged 5-14 years), the control group included 20 non-asthmatic children (7 girls, 13 boys) aged 5-10 years with carious lesions in teeth, and the differences were considered statistically significant at a $p$ level of $<0.05$, and the differences were considered statistically significant at a p level of $<0.05$.

The dental examination was carried out based on the standard methods with an informed consent from all parents. In this case, we studied the prevalence and intensity of the carious process of primary teeth using the DMF index (permanent dentition), DMF + df index (mixed dentition) and df index (primary dentition). The World Health Organization (WHO) criteria were used to assess the prevalence and intensity of dental caries. The prevalence of caries is the percentage $(\%)$ of children with decayed, filled primary or permanent teeth and missing permanent teeth from the total number of the children examined [15]. The intensity of the lesion is the average number of decayed teeth (namely, caries lesion and its complications) (D, d), filled $(F, f)$ teeth and missing (M) teeth for one child examined (Table 1) [16].

The presence of decayed, missing or filled teeth, the number of dental decay cavities and their localization were regarded as symptoms of caries, which allowed determining the degree of the pathological process (Table 2) [15].

\section{Results}

According to the study conducted, the following results were obtained. Among 158 children with bronchial asthma, 10 children were caries free. The pathological process prevalence was $95.5 \%$ indicating the mass disease based on the WHO criteria.

The clinical results in the group of children with a permanent dentition, which included 79 persons and consisted of two subgroups: girls ( 20 persons), boys ( 59 persons) aged $14(13 ; 16) \min 10$, max 17 years, indicated a high level of carious process intensity with the DMF index equal to $6(4 ; 8)$ $\min 1$, max 16 , while $75 \%$ of the children had a subcompensated and $25 \%$ of the children had a compensated carious process according to the WHO. A comparison between subgroups of girls and boys by age and DMF index was performed. In the study group, boys were older than girls, 
but the difference did not reach a statistical significance: 14 $(13 ; 16)$ versus $14.0(13.0 ; 14.5)$ years. However, the carious process intensity in boys was significantly higher: 6.0 $(4.5 ; 8.0)$ versus $5(4 ; 8)$, which testified to sex differences in the pathological process of the oral cavity.

In the group of children with mixed dentition, which included 59 persons ( 21 girls and 38 boys) aged $9(8 ; 10)$ $\min 5$, max 14 years, the DMF + df index was equal to 7 $(4 ; 10) \min 1, \max 14$, and testified to a very high intensity of the carious process according to the $\mathrm{WHO}$, and in this case, $25 \%$ of children had a compensated carious process, $25 \%$ of children - subcompensated and $50 \%$ of children decompensated one. When comparing the subgroups of girls and boys, no age- and sex-specific characteristics regarding the DMF + df index were revealed.

The group with a primary dentition consisted of 10 children ( 6 girls and 4 boys) aged $4(3 ; 4) \min 3$, max 6 years. The df index in this age group was equal to $4(2 ; 4)$ $\min 1$, max 12 . The comparison between the subgroups of girls and boys by sex and age relative to df indicator was not performed. When comparing the carious process intensity in groups according to the Kruskal-Wallis test, a statistically significant difference was observed $(H=9.08$, $P=0.0107$ ) (Table 3.)

Since the greatest prevalence of dental caries was observed in the mixed dentition, a comparison was made with healthy children included in the control group relating to asthma by the DMF + df index (20 children: 7 girls, 13 boys, aged $8(7 ; 9) \min 5, \max 10)$. There was a statistically significant difference $(P<0.05)$ indicating that in children with bronchial asthma, the intensity of the carious process was higher $(7(4 ; 10) \min 1$, max 14 versus $6.0(3.5 ; 8.0)$ $\min 1, \max 10)$ (Fig. 1).

\section{Discussion}

Having analyzed the modern medical literature, we found that the issue had been insufficiently studied in Ukraine. So, within the territory of our country, only few scientists were engaged in such studies. In 2012, M. V. Anisimov and O. V. Denha conducted a study on the carious process intensity in 101 patients with allergic diseases aged between 18 and 40 years. The results obtained showed a very high level of dental caries intensity (with DMF index of 9.6 in males and 10.0 in females) [17]. In 2014, O. Y. Vydoinik and O. V. Avdieiev examined 240 children with bronchial asthma aged $7-15$ years and determined the incidence of complicated dental caries in primary and permanent teeth in comparison with children of the control group (100 children without concomitant somatic pathologies). The results obtained have shown that the risk of complicated dental caries in children with bronchial asthma is at least twice as high as that in other age-matched children without any concomitant somatic pathology [18]. And only in 2013, S. E. Leshchuk and N. I. Smoliar, having examined 262 children aged between 3 and 12 years with bronchial asthma and compared the results obtained with 343 somatically healthy children, found the high dental caries prevalence $(74.49 \pm 8.12 \%)$ and the average level of the pathological process intensity $(3.52 \pm 0.52)[19,20]$. However, none of the researchers studied the carious process prevalence and intensity in detail. Furthermore, the data obtained in our study differed
Table 3. The carious process intensity in children with bronchial asthma in groups with a mixed, permanent and primary dentition.

\begin{tabular}{l|l|l|l|l|l|l}
\hline & \multicolumn{9}{l}{ Age } & \multicolumn{2}{l}{ Intensity } \\
\cline { 2 - 8 } & Mentition & $\begin{array}{l}\text { Lower } \\
\text { quartile } \\
\text { Q25 }\end{array}$ & $\begin{array}{l}\text { Upper } \\
\text { quartile } \\
\text { Q75 }\end{array}$ & Me & $\begin{array}{l}\text { Lower } \\
\text { quartile } \\
\text { Q25 }\end{array}$ & $\begin{array}{l}\text { Upper } \\
\text { quartile } \\
\text { Q75 }\end{array}$ \\
\hline Permanent dentition & 14 & 13 & 16 & 6 & 4 & 8 \\
\hline Mixed & 9 & 8 & 10 & 7 & 4 & 10 \\
\hline Primary & 4 & 3 & 4 & 4 & 2 & 4 \\
\hline
\end{tabular}

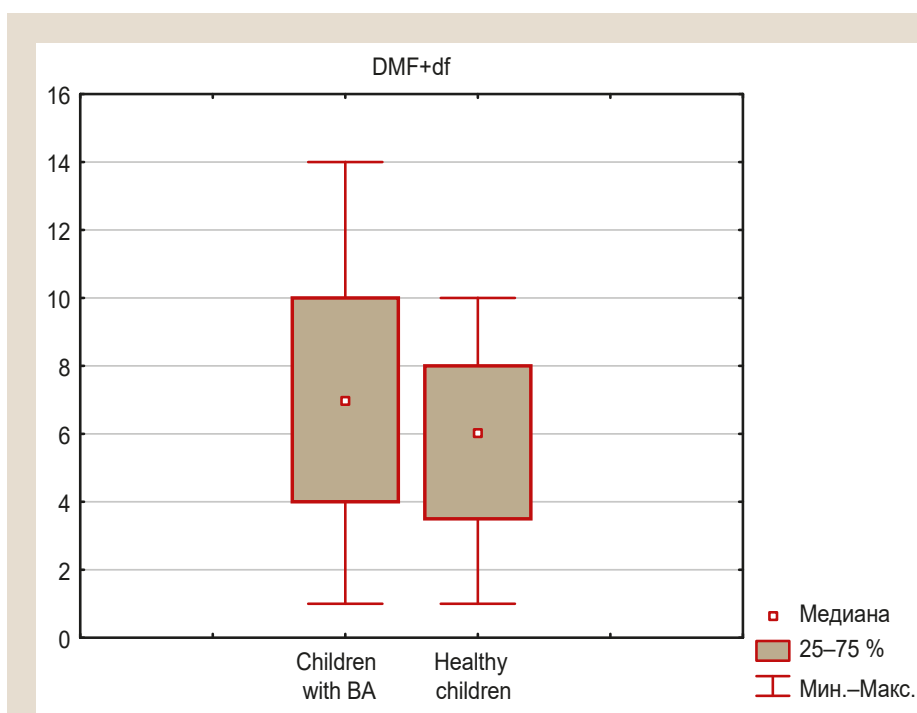

Fig. 1. Caries lesion in the period of mixed dentition in children with bronchial asthma (BA) and healthy children.

from those presented above. This gives us an opportunity to study further the presented issue.

\section{Conclusions}

The study conducted for the state of dental hard tissues has proven the high prevalence and intensity of the carious process in children with bronchial asthma. In addition, the data obtained have enabled us to determine the presence of sex-specific characteristics and differences in the reported indicators in adolescents. This motivates us to study the dental health issues in children with bronchial asthma in the anamnesis and to develop specific programs for the prevention of dental caries.

Prospects for further studies. In the future, we are planning to study the composition of plaque microflora, $\mathrm{pH}$ of saliva and its viscosity in children with bronchial asthma to identify etiologically significant aspects of the dental caries development.

Funding

The study conducted is a fragment of the scientific and research work of the Department of Faculty Pediatrics on the topic: "Optimization of differential diagnostics and treatment of allergic and other diseases in children of different ages" (state registration number 0118U004254).

Conflicts of interest: authors have no conflict of interest to declare. Конфмікт інтересів: віАсутній. 
Налійшла Ао реАакції / Received: 28.08.2019

Після Аоопрацювання / Revised: 27.09.2019

Прийнято Ао Аруку / Accepted: 09.10.2019

Information about authors:

Voznyi A. V., MD, PhD, DSc, Head of the Department of Therapeutic, Orthopedic and Pediatric Dentistry, Zaporizhzhia State Medical University, Ukraine.

Shumna T. Ye., MD, PhD, DSc, Professor of the Faculty Pediatric Department, Zaporizhzhia State Medical University, Ukraine. Lepetchenko Ye. S., MD, Postgraduate Student of the Department of Therapeutic, Orthopedic and Pediatric Dentistry, Zaporizhzhia State Medical University, Ukraine.

\section{Відомості про авторів:}

Возний О. В., А-р меА. наук, Аоцент, зав. каф. терапевтичної, ортопеАичної та Аитячої стоматології, Запорізький Аержавний медичний університет, Україна.

Шумна Т. Є., А-р мед. наук, професор каф. факультетської педіатрії, Запорізький Аержавний медичний університет, Україна. Лепетченко Є. С., аспірант каф. терапевтичної, ортопедично та Аитячої стоматології, Запорізький Аержавний меАичний університет, Україна.

\section{Сведения об авторах:}

Возный А. В., А-р меА. наук, Аоцент, зав. каф. терапевтической, ортопедической и Аетской стоматологии, Запорожский государственный медицинский университет, Украина. Шумная Т. Е., А-р меА. наук, профессор каф. факультетской педиатрии, Запорожский государственный меАицинский университет, Украина.

Лепетченко Е. А., аспирант каф. терапевтической, ортопеАической и Аетской стоматологии, Запорожский государственный медицинский университет, Украина.

\section{References}

[1] Bezvushko, E. V. (2013). Stomatolohichna zakhvoriuvanist ditei, yak prozhyvaiut na riznykh za ekolohichnym stanom terytoriiakh, ta obgruntuvannia dyferentsiiovanoi profilaktyky urazhen tverdykh tkanyn zubiv. (Avtoref. dis. ... dokt. med. nauk) [Dental incidence of children living in different ecologically diverse regions, and substantiation of differentiated prevention of hard tissue lesions. Dr. med. sci. diss.] Kyiv. [in Ukrainian].

[2] Khomenko, L. O., Ostapko, O. I., \& Trachuk Yu. M. (2007). Stan tverdykh tkanyn postiinykh zubiv u ditei v riznykh za ekolohichnoiu sytuatsiieiu rehionakh Ukrainy [Condition of hard tissues of permanent teeth in children living in different ecological regions of Ukraine]. Novyny stomatolohii, (1), 87-91. [in Ukrainian]

[3] Savichuk, N. O., \& Savichuk, A. V. (2008). Profilaktika i lechenie nachal'nogo kariesa zubov u detei [Prevention and treatment of initial dental caries in children]. Therapia. Ukrainskyi medychnyi visnyk, (12), 53-56. [in Russian].

[4] Moiseenko, R. A., Danilenko, G. N., \& Ponomareva, L. I. (2013). Osoblyvosti dynamiky zdorovia uchniv pochatkovoi ta osnovnoi shkoly [The features of health dynamics of pupils of the primary and middle school]. Sovremennaya pediatriya, (1), 13-17. [in Ukrainian].

[5] Peresychny, M. I., Karpenko, P. O., \& Khlibichuk, V. O. (2012). Naukova kontseptsiia orhanizatsii ratsionalnoho kharchuvannia uchniv zahalnoosvitnikh i profesiino-tekhnichnykh navchalnykh zakladiv [The scientific conception of the rational nutrition organization of students of general and vocational secondary schools]. Problemy kharchuvannia, (1), 33-35. [in Ukrainian].

[6] Pukhlik, B. M., \& Zabolotnyi D. I. (2002). Aktual'nye problemy lekarstvennoi allergii [Actual problems of drug allergy]. Likuvannia ta diahnostyka, (3), 29-34. [in Russian].

[7] Antypkin, J. G., Umanets, T. R., Lapshin, V. F., Nakonechna, A. A Matveeva, S. U., \& Pustovalova, O. I. (2014). Bronkhialna astma, poiednana $z$ alerhichnym rynitom, u ditei: mistse antyhistaminnykh preparativ u likuvanni [Bronchial asthma along with allergic rhinitis in children: value antihistamines in treatment]. Astma $i$ alerhiia, (4), 60-65. [in Ukrainian].

[8] Kaskova, L. F., \& Shepelia, A. V. (2009). Vplyv profilaktychnykh zakhodiv na biokhimichni pokaznyky rotovoi ridyny $v$ ditei molodshoho viku [Influence of preventive measures on biochemical parameters of oral fluid in young children]. Ukrainskyi stomatolohichnyi almanakh, (6), 54-57. [in Ukrainian].
[9] Zabelina, N. A. (2000). Skorost' slyunootdeleniya i nekotorye parametry rotovoi zhidkosti u detei, bol'nykh allergodermatozamiyu [The salivation rate and some parameters of the oral fluid in children with allergic dermatosis]. Sovremennaya stomatologiya, (1), 32-33. [in Russian].

[10] Anjomshoaa, I., Cooper, M. E., \& Vieira, A. R. (2009). Caries is Associated with Asthma and Epilepsy. European journal of dentistry, 3(4), 297-303.

[11] Stensson, M., Wendt, L. -K., Koch, G., Nilsson, M., Oldaeus, G., \& Birkhed, D. (2010). Oral health in pre-school children with asthma-followed from 3 to 6 years. International journal of paediatric dentistry, 20(3), 165-172. https://doi.org/10.1111/j.1365-263X.2010.01037.x

[12] Tanaka, K., Miyake, Y., Arakawa, M., Sasaki, S., \& Ohya, Y. (2008) Dental Caries and Allergic Disorders in Japanese Children: The Ryukyus Child Health Study. Journal of Asthma, 45(9), 795-799. https://doi. org/10.1080/02770900802252119

[13] Mazzoleni, S., Stellini, E., Cavaleri, E., Angelova Volponi, A., Ferro, R. \& Fochesato Colombani, S. (2008). Dental caries in children with asthma undergoing treatment with short-acting beta2-agonists. European journal of paediatric dentistry, 9(3), 132-138.

[14] Nazaryan, R. S., Ydovichenko, N. N., \& Spiridonova, K. U. (2013) Sravnitel'nyi analiz pokazatelei rasprostranennosti i intensivnosti kariesa zubov u detei v vozraste ot 6 do 11 let Khar'kovskogo regiona [Comparative analysis of the prevalence and intensity of dental caries in children from 6 to 11 years old of Kharkov region]. Svit medytsyny ta biolohii, 9(2-2), 153-154. [in Russian].

15] Khomenko, L. A., Kisel'nikova, L. P., Smolyar, N. I., Chaikovskii, Yu. B. Vasil'ev, A. Yu., Ostapko, E. I., Bidenko, N. V., Savichuk, A. V., Smyslenova, M. V., Golubeva, I. N., Lyuberets, S. F., Alpatova, V. G. Vasil'eva, N. Yu., Voznyuk, V. P., Eradze, E. P., Kovylina, O. S. Kononovich, E. F., Moskalenko, A. N., Ozhgikhina, N. V., Petrovskaya, V. V., Solon'ko, G. M., \& Shmatko, V. I. (2013). Terapevticheskaya stomatologiya detskogo vozrasta [Pediatric therapeutic dentistry]. Kniga-Plyus. [in Russian]

[16] Danylevskyi, M. F., Borysenko, A. V., Politun, A. M., Sidelnikova, L. F., \& Nesyn, O. F. (2004). Terapevtychna stomatolohiia. T. 2 [Therapeutic dentistry. Vol. 2]. Zdorovia. [in Ukrainian].

[17] Anisimov, M. V., Anisimova, L. V., \& Den'ga, O. V. (2012). Osobennost stomatologicheskogo statusa patsientov s otyagoshchennym allergoanamnezom [Features of the dental status of patients with a burdened allergic history]. Dental'nye tekhnologii, (3-4), 14-18. [in Russian].

[18] Vydoynyk, O., \& Avdeev, O. (2014). Chastota uskladnenykh form ta stupin aktyvnosti karioznoho protsesu u ditei, khvorykh na bronkhialnu astmu [Complication Rate Forms and Degree of Activity of Caries Process Children with Bronchial Asthma]. Visnyk problem biolohii ta medytsyny, 4(4), 321-323. [in Ukrainian].

[19] Leshchuk, S. Ye. (2013). Urazhenist kariiesom molochnykh zubiv u ditei $z$ bronkhialnoiu astmoiu u vikovomu aspekti [Caries of baby teeth in children with bronchial asthma in age aspects]. Visnyk stomatolohii, (2), 112. [in Ukrainian].

[20] Smolar, N. I., \& Leshchuk, S. Ye. (2013). Osoblyvosti klinichnoho perebihu kariiesu tymchasovykh zubiv u ditei iz bronkhialnoiu astmoiu [Features of the clinical course of caries of primary teeth in children with bronchial asthma]. Bukovynskyi medychnyi vistnyk, 17(3, Pt. 2) 72-75. [in Ukrainian] 